\title{
The complete sequence of the mitochondrial genome of the Chinook salmon, Oncorhynchus tshawytscha.
}

\author{
VIVIAN WILHELM ${ }^{1,2}$, JAIME VILLEGAS $^{1,2}$, ÁLVARO MIQUEL $^{3}$, ESTEBAN $^{2}$ \\ ENGEL $^{1,2}$, SEBASTIÁN BERNALES ${ }^{1,2}$, PABLO D.T. VALENZUELA ${ }^{1,2}$ AND LUIS O. \\ BURZIO $^{1,2,3}$
}

${ }^{1}$ Fundación Ciencia para la Vida, ${ }^{2}$ Instituto Milenio de Biología Fundamental y Aplicada, MIFAB, and ${ }^{3}$ Bios Chile I.G.S.A. Avenida Marathon 1943, Santiago, Chile

\begin{abstract}
The complete sequence of the mitochondrial genome of Chinook salmon, Oncorhynchus tshawytscha, has been determined. The circular genome consisting of 16,644 base pairs encodes thirteen proteins, the $12 \mathrm{~S}$ and $16 \mathrm{~S}$ ribosomal RNAs, and 22 transfer RNAs. These genes are ordered in the same way as most other vertebrates. The nucleotide and amino acid sequences of the ribosomal RNAs and the thirteen protein-coding genes were compared with those of other salmonids such as Oncorhynchus mykiss, Salmo salar, Salvelinus fontinalis, Salvelinus alpinus and Coregonus lavaretus. The sequence features of the control region (D-loop), the origin of L-strand replication and a putative peptide codified by the $16 \mathrm{~S}$ mitochondrial RNA are described and discussed.
\end{abstract}

Key terms: Salmonids, Mitochondria, Genome, Peptides, 16S rRNA

\section{INTRODUCTION}

Since the publication of the complete sequence of the human mitochondrial DNA (mtDNA) by Anderson et al., (1981), the organization of the mitochondrial genome of a variety of organisms including multicellular animals, plants, fungi and protozoa has been well characterized (Wolstenholme, 1992). At present, the mtDNA of 67 fish have been sequenced (NCBI: www.ncbi.nlm.nih.gov/PMGifs/ Genomes/ 7898.html). Due to the relative lack of recombination of the mtDNA and its maternal mode of inheritance, the mitochondrial genome represents a useful marker to use in population and phylogenetic studies. In this regard, the salmonid fish are commercially important, and the farming of these fish represents a major economic activity in Norway, Chile, Canada, Scotland, and elsewhere. Consequently, there is great interest in knowing the genetic features of the mitochondrial DNA for stock identification, management, conservation, and population studies (Phillips and Oakley, 1997). Within this genus the complete sequence of the mtDNA of the rainbow trout $O$. mykiss (Zardoya et al., 1995) was followed by the sequence of the mtDNA of Atlantic salmon S. salar (Hurst et al., 1999), and other salmonids such as S. alpinus (Doiron et al., 1999), C. lavaretus (Miya and Nishida, 2000) and S. fontinalis (Doiron et al., 2002). Similar to other vertebrates, the organization of the mtDNA of salmonid fish species contains 13 protein coding genes, 22 transfer tRNA genes, and 2 ribosomal RNAs genes corresponding to the $12 \mathrm{~S}$ and $16 \mathrm{~S}$ transcripts.

Recently we have been involved in sequencing the complete genome of Piscirickettsia salmonis (Valenzuela et al., 2001), the causative agent of SRS, a disease with negative consequences for the salmon farming industry (Fryer and Mauel, 1997). $P$. salmonis is a Gram-negative obligate 
intracellular bacterium found in cytoplasmic vacuoles of infected cells. To grow the pathogen, fish cells such as CHSE-214 obtained from Chinook salmon $(O$. tshawytscha) (Lannan et al., 1984) are infected with the bacteria, and after 10 to 12 days, P. salmonis is harvested (Jamett et al., 2001). To achieve the purification of the bacterial DNA and to eliminate contamination from CHSE-214 cell DNA, we developed a procedure based on the treatment with DNAse I. To avoid the alteration of the bacterial membranes and the consequent destruction of the $P$. salmonis DNA, we developed a buffer solution to preserve the integrity of the bacterial cells. This condition involves the suspension of the purified microorganisms in a solution that also stabilized the mitochondria of the CHSE-214 cells. Therefore our final preparation of DNA of $P$. salmonis was contaminated with the mitochondrial DNA of Chinook salmon. We accepted this risk as the low complexity of the mitochondria genome would not alter the assembly of the different fragments of the shotgun library into contigs. Here we present the complete sequence of the mtDNA of Chinook salmon based on 8 contigs that were completed by PCR amplification to close the gaps. The sequence features of the control region (D-loop), the origin of replication of the L-strand replication, and a putative peptide codified by the $16 \mathrm{~S}$ mitochondrial RNA, are discussed.

\section{MATERIALS AND METHODS}

Growth of P. salmonis in Chinook salmon cells.

P. salmonis LF-89 (ATCC VR 1361) were continuously propagated in Chinook salmon embryo cell line CHSE-214 (CRL 1681 ATCC) (Lannan et al. 1984) using the antibiotic-free Minimal Essential Medium (MEM) plus $5 \%$ bovine serum as described elsewhere (Jamett et al. 2001). To follow the growth of the pathogen, the amount of bacteria in the culture medium was evaluated by using an ELISA test for $P$. salmonis (Aguayo et al., 2002).
Purification of P. salmonis and Chinook salmon mitochondria.

When the cytopathic effect on the CHSE214 was more than $90 \%$, the lysate was collected from the culture flasks and centrifuged at 200xg. The pellet containing $P$. salmonis and cellular debris was resuspended in a modified PBS solution containing $200 \mathrm{mM} \mathrm{NaCl}$ (Jamett et al., 2001) and centrifuged at $200 \mathrm{x} \mathrm{g}$. This washing procedure was repeated once, and the final pellet, referred to as the partiallypurified fraction of $P$. salmonis (Jamett et al. 2001), was resuspended in $5 \mathrm{ml}$ of the PBS-200 mM NaCl solution. To determine the number of bacteria per ml, serial dilutions in the PBS-200 mM NaCl solution were counted under phase microscopy in a Neubauer chamber. Using this procedure, one $\mathrm{mg}$ of protein corresponds to approximately $3.8 \times 10^{9} \mathrm{P}$. salmonis (Jamett et al. 2001).

\section{DNA isolation}

The partially-purified $P$. salmonis fraction was resuspended in $5 \mathrm{ml}$ of a solution containing $50 \mathrm{mM}$ Tris- $\mathrm{HCl}, \mathrm{pH} 7.5,200 \mathrm{mM}$ $\mathrm{NaCl}, 2 \mathrm{mM} \mathrm{KCl}, 5 \mathrm{mM} \mathrm{MgCl} 2,0.1 \mathrm{mM}$ $\mathrm{CaCl} 2,2 \mathrm{mM}$ 2-mercaptoethanol, $2 \mu \mathrm{g} / \mathrm{ml}$ of aprotinin and $2 \mu \mathrm{g} / \mathrm{ml}$ of leupeptin. To this mixture, $350 \mu \mathrm{g}$ of Dnase I and $350 \mu \mathrm{g}$ of Rnase A were added and then incubated at $25^{\circ} \mathrm{C}$ for $60 \mathrm{~min}$. To stop the reaction, 20 volumes of PBS containing $200 \mathrm{mM} \mathrm{NaCl}$ and $1 \mathrm{mM}$ EDTA were added, and the mixture was centrifuged at $7,000 \mathrm{x}$ g for 20 min. The bacterial pellet was washed once more with the above PBS solution and the final pellet was resuspended in $5 \mathrm{ml}$ of the lysis buffer (50 mM Tris- $\mathrm{HCl}, \mathrm{pH} 9.0,400$ $\mathrm{mM} \mathrm{NaCl}, 20 \mathrm{mM}$ EDTA, $0.5 \mathrm{M}$ sucrose and $0.2 \% \mathrm{SDS}$ ). To the suspension, $1 \mathrm{mg}$ of proteinase $\mathrm{K}$ was added, and the mixture was incubated at $58^{\circ} \mathrm{C}$ for $60 \mathrm{~min}$. The DNA was then extracted with the phenol procedure as described (Sambrook et al, 1989). To check for the absence of nuclear salmon DNA, the preparation was used as a template to amplify the $18 \mathrm{~S}$ ribosomal gene (forward: 5' ACGGCCGGTACAGTGAAACT; reverse: 
5. CCAATTACAGGGCCTCGAAA) (Villegas et al., 2000). Those preparations of the bacteria DNA without contamination with salmon DNA were used for sequencing.

\section{DNA sequencing}

The mixture of bacterial and mitochondrial DNA purified as described was sequenced by the whole-genome shotgun approach as described before for the complete sequence of several bacteria (Stover et al., 2000). The DNA was fragmented by nebulization to an average size of approximately 1,000 bp. The random fragments were cloned into the pIK96 plasmid using the BstXI adaptors, provided by Incyte Genomics Inc. A total of 18,887 sequence reads were obtained during the random sequencing phase using ABI 3700 sequencers at Incyte Genomics Inc. (Palo Alto, CA) and ABI 310 DNA sequencers in our laboratory.

\section{Bioinformatics}

The sequences of the fragments were assembled and edited into contigs using the SEQUENCHER 4.1 and the Vector NTI 6.1 programs. The gaps between contigs corresponding to the mitochondrial DNA were closed and sequenced by PCR (Villegas et al., 2002) and with primers designed according to the sequence adjacent to the 3 ' and 5' ends of the corresponding contigs. The mitochondrial genes were identified using the sequence-alignment algorithms BLASTX and BLASTP (Altschul et al., 1997) and the complete mitochondrial genome of the salmonids O. mykiss (NC_001717), S. salar (U12143), S. alpinus (AF154851), S. fontinalis (NC_000860) and C. lavaretus (AB034824).

RESULTS AND DISCUSSION

\section{Genome Organization}

As described in Methods, a fraction of the DNA preparation of $P$. salmonis corresponded to the mtDNA of CHSE-214 cells used to grow the bacteria (Jamett et al., 2001). Within the 2,143 contigs assembled from 18,887 reads of the bacterium genome, we identify 8 contigs that correspond to the mtDNA of $O$. tshawytscha. The 9 gaps were closed by PCR, followed by a cloning of the corresponding amplicon and sequencing. The complete sequence of $O$. tshawytscha contains $16,644 \mathrm{bp}$, and it has been deposited in the NCBI/GeneBank libraries under the accession number NC_002980.

To date, the complete sequence of 67 mitochondrial genomes of fish have been deposited in the GeneBank (www.ncbi.nlm. nih.gov/ PMGifs/ Genomes/7898.html), including the mtDNA of six salmonid species. The size of the mtDNA of $O$. tshawytscha is similar to those of other salmonids such as $O$. mykiss (16,642 bp), $S$. salar (16,665 bp), S. fontinalis (16,624 bp), $S$. alpine $(16,659 \mathrm{bp})$ and $C$. lavaretus $(16,737 \mathrm{bp})$. The genome comprises 2 ribosomal genes, 13 protein-encoding genes, 22 tRNAs, and the control region. The position and orientation of the mitochondrial genes and the control region are similar to those described in most other fish and higher vertebrates (Fig. 1). The overlapping arrangement between the set of genes ATP8/ATP6 and ND4L/ND4 were 10 and $7 \mathrm{bp}$, respectively. This overlapping is identical to that found in O. mykiss, $S$. salar, S. alpinus, $S$. fontinalis and $C$. lavaretus. Although the genes of ND5 and ND6 are encoded in the $\mathrm{H}$ and L-strand, respectively, the overlapping is also similar to that found in the other salmonids.

\section{Protein-Encoding Genes}

The Chinook salmon mtDNA contains 13 open reading frames, 12 codified by the $\mathrm{H}$ strand and one (ND6) codified by the Lstrand (Fig. 1). In general, there is a high homology of sequences at the nucleotide and amino acid level when they are compared with other salmonid species (Table I). All the initiation codons are ATG except that of COI gene, which is GTG. This initiation codon also has been described in other fish 


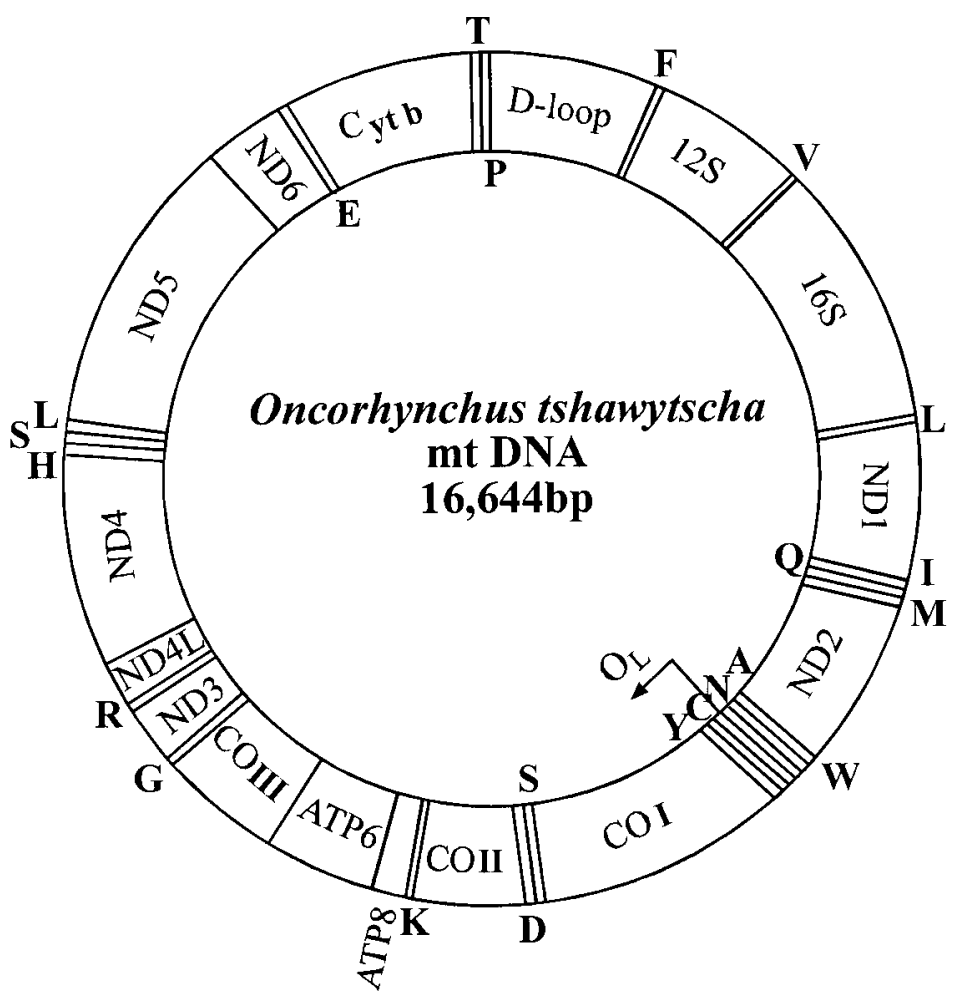

\section{Figure 1}

The organization of the mitochondrial genome of $O$. tshawytscha. The outer and the inner circles represent the $\mathrm{H}$ - and L-strands, respectively. The tRNA genes are indicated by the single letter amino acid code.

\section{TABLE I}

Percentage of nucleotide (Nt) and amino acid (AA) sequence identities of $O$. tshawytscha mitochondrial genes against their homologues of other salmonids.

\begin{tabular}{|c|c|c|c|c|c|c|c|c|c|c|}
\hline \multirow[b]{2}{*}{ Genes } & \multicolumn{2}{|c|}{ O. mykiss } & \multicolumn{2}{|c|}{ S. salar } & \multicolumn{2}{|c|}{ S. fontinalis } & \multicolumn{2}{|c|}{ S. alpinus } & \multicolumn{2}{|c|}{ C. lavaretus } \\
\hline & $\mathrm{Nt}$ & AA & $\mathrm{Nt}$ & AA & $\mathrm{Nt}$ & AA & $\mathrm{Nt}$ & AA & $\mathrm{Nt}$ & AA \\
\hline $12 \mathrm{~S}$ rRNA & 97.3 & - & 96.0 & - & 96.3 & - & 96.5 & - & 94.9 & - \\
\hline $16 \mathrm{~S}$ rRNA & 96.4 & - & 95.6 & - & 95.7 & - & 95.8 & - & 94.7 & - \\
\hline NAD 1 & 91.6 & 100 & 86.1 & 96.9 & 85.4 & 97.5 & 87.0 & 98.1 & 82.4 & 96.9 \\
\hline NAD 2 & 90.2 & 95.4 & 86.0 & 94.0 & 85.6 & 92.8 & 85.6 & 92.8 & 78.6 & 87.1 \\
\hline COI & 93.8 & 99.8 & 87.8 & 99.0 & 89.5 & 99.4 & 89.6 & 99.4 & 85.2 & 99.0 \\
\hline COII & 94.1 & 98.3 & 92.5 & 97.8 & 90.8 & 97.8 & 91.0 & 97.8 & 88.0 & 97.4 \\
\hline ATP8 & 96.4 & 100 & 98.2 & 100 & 95.2 & 98.1 & 95.8 & 96.4 & 95.8 & 100 \\
\hline ATP6 & 89.0 & 97.8 & 87.4 & 97.8 & 85.6 & 98.2 & 85.7 & 98.2 & 83.6 & 97.8 \\
\hline COIII & 86.2 & 95.8 & 89.9 & 97.3 & 88.5 & 96.5 & 90.3 & 96.9 & 86.2 & 95.8 \\
\hline NAD 3 & 92.5 & 99.1 & 84.5 & 94.0 & 88.5 & 95.7 & 86.5 & 94.0 & 79.3 & 93.2 \\
\hline NAD 4L & 94.6 & 100 & 91.2 & 99.0 & 89.8 & 100 & 89.6 & 100 & 88.5 & 100 \\
\hline NAD 4 & 91.3 & 97.8 & 86.9 & 97.2 & 85.9 & 96.7 & 87.5 & 96.5 & 83.0 & 97.8 \\
\hline NAD 5 & 92.4 & 96.9 & 87.6 & 94.3 & 87.0 & 93.4 & 87.6 & 94.0 & 82.5 & 91.3 \\
\hline NAD 6 & 92.3 & 98.8 & 86.0 & 94.2 & 86.9 & 95.3 & 86.0 & 96.5 & 81.8 & 95.3 \\
\hline Cyt b & 92.1 & 99.2 & 87.8 & 98.7 & 88.1 & 98.4 & 87.8 & 98.4 & 84.5 & 98.4 \\
\hline
\end{tabular}


species including the other salmonids described before. On the other hand, the termination codon TAA is present in the ORF of COI, ATP8, ATP6, COIII, ND4L and $N D 5$, whereas codon TAG is present in $N D 1$, $N D 2$ and ND6. In the later gene, this termination codon is present in all the mtDNA of salmonids species so far sequenced. For the other genes, the TAG termination codon varies among the species. The four remaining genes (COXII, ND3, ND4, Cyt b) do not end with a complete stop codon but with single T. In humans (Ojala et al., 1981) and in Xenopus (Roe et al., 1985) it was demonstrated that the transcript of these gene contains a complete termination codon TAA created by post-transcriptional polyadenylation. It is reasonable to argue that a similar situation takes place after transcription of these mitochondrial genes in O. tshawytscha as well as in other salmonids that also contain incomplete TAA termination codon in their mitochondrial genome, as suggested previously (Zardoya et al., 1995; Hurst et al., 1999).

\section{Ribosomal and transfer RNA}

The $12 \mathrm{~S}$ and $16 \mathrm{~S}$ rRNA genes in $O$. tschawytscha mtDNA are 947 and 1,683 bp long, respectively. Similar to other vertebrates, the rRNA genes are located between tRNA $^{\text {Phe }}$ and tRNA ${ }^{\text {Leu }}$ (UUR) and are separated by tRNA ${ }^{\text {Val }}$ (Fig. 1). Alignment of the ribosomal genes with those of other salmonids revealed high identity values, indicating that they are highly conserved among these species (Table I). On the other hand, alignment with the corresponding genes of other fish and mammals revealed a typical pattern of conserved segments interrupted by variable sequences (data not shown).

An interesting feature found in the $16 \mathrm{~S}$ rRNA is the presence of short ORFs as shown in Figure 2, using the vertebrate mitochondrial code. If the sequences of the salmonids $16 \mathrm{~S}$ rRNAs are used to run any program for nucleic acid translation, several peptides of different length are identified and only a few of them began with Met. Therefore, the only ORFs selected were those that corresponded to a minimum of 24 amino acids, present in approximately the same position in the $16 \mathrm{~S}$ rRNA and which show high amino acid homology among the six salmonids species considered in this study. In O. tschawytscha an ORF for a peptide of 46 amino acids and codified by the $\mathrm{H}$-strand between positions 976 and 1,113 was found (Fig. 2). The amino acid sequence of this peptide shows a $97.8 \%$ of identity with similar peptides found in the other salmonid species and with similar position in the 16S rRNA (Fig. 2). An ORF corresponding to a second peptide around position 1223 and 1377 of the H-strand of the $16 \mathrm{~S}$ rRNA was also found. However, this

\section{O. tshawytscha MGLTAAVEWPCEGSAITCLLNEDLYEWHAEGLAVSSFRSMILICPC}

$(976-1113)$

S. salar MGLTAAVFWPCEGSAITCLINEDLYEWHHEGLAVSSSRSYIIICPC

$(973-1110)$

O. mykiss

MGLTAAVEWPCEGSAITCLINEDLYEWHHEGLAVSSSKSYIRLICPC

$(970-1107)$

S. fontinalis

MGLTAAVEWPCEGSAITCLINEDLYEWHHEGLAVSSPKSMIKIICPC

$(973-1110)$

S. alpinus

MGLTAAVFWPCEGSAITCLINEDLYEFHAEGLAVSSPKSMIKLICPC

$(973-1110)$

C. lavaretus

MGLTAAVEWPCEGSAITCLINEDLYEFHHEGLAVSSSKSVKLICPC

$(971-1108)$

Figure 2

Sequences of the peptide-coding ORF in the $16 \mathrm{~S}$ ribosomal RNA of the O. tshawytscha and five other salmonids. The numbers in parenthesis at the right of each sequence correspond to the position in the $16 \mathrm{~S}$ rRNA. 
peptide shows less identity between the salmonids and variation in the length between 49 ( $S$. salar) and 60 (O. mykiss) amino acids (data not shown). In addition to the restriction imposed on selecting the peptide, it is reasonable to ask whether they have a physiological meaning. This search was inspired by recent work that described a peptide of 24 amino acids, referred to as humanin, a factor that protects the neuronal cell from the apoptosis that occurs in familial Alzheimer's disease (Niikura et al., 2002). The human $16 \mathrm{~S}$ mitochondrial gene codifies this peptide and the ORF is in positions 963 to 1037 , similar to the positions where we found the ORF in the salmonid ribosomal RNA (Fig. 2). Therefore, it might be possible that these putative peptides play a functional role in salmonids. This finding might be another surprise of the pleitrophic features of the $16 \mathrm{~S}$ mitochondrial RNA in addition to other intriguing properties such as nuclear localization (Villegas et al., 2000; 2002), cytoplasmic localization, the role in the development of the germ cell line (Kobayashi et al., 1998), and the chaperonelike activity (Sulijoadikusumo et al., 2001).

\section{tRNA sequences}

Similar to other vertebrates, the mtDNA of O. tshawytscha contains 22 tRNA genes interspersed between ribosomal RNAs and protein encoding regions. Fourteen tRNAs are codified by the $\mathrm{H}$-strand and 8 are codified by the L-strand, similar to the organization in other salmonids. As reported before, the tRNA ${ }^{\text {Met }}$ is quite well conserved, showing high identity with the sequence found in $S$. salar, O. mykiss, $S$. alpinus, $S$. fontinalis, $C$. lavaretus (data not shown). The DHU loop of tRNA ${ }^{\text {Leu }}$ (UUR) is highly conserved among vertebrates and the sequence of this loop shows high identity with those of $O$. mykiss, S. salar and other salmonids (data not shown). The sequence of this loop has been proposed as necessary for the correct stop of transcription of the ribosomal RNAs plus the included tRNAs (Shadel and Clayton, 1997). This is an important control region of transcription of the mtDNA to allow the synthesis of as many copies of the rRNAs needed for translation (Shadel and Clayton, 1997; Taanman, 1999). All the tRNAs of $O$. tschawytscha can be folded into the cloverleaf secondary structures (data not shown), and this folding requires the formation of G-U pairing as reported before (Wolstenholme, 1992).

In contrast with the other tRNAs, the tRNA $^{\text {Ser }}$ (AGY) contains a complete DHU arm, which is missing in the rest of the homologous tRNAs and as proposed previously, this is an exception conserved in fish (Wolstenholme, 1992).

\section{The Control Region}

Between the tRNA ${ }^{\text {Pro }}$ and tRNA ${ }^{\text {Phe }}$ genes of vertebrates mtDNAs there is a non-coding region that varies in length (Wolstenholme, 1992). Because in mammals and amphibians this sequence has been shown to include the signals required for the initiation of the $\mathrm{H}$ strand replication, and it has been designated as the control region for both $\mathrm{H}$-strand and L-strand transcription (Shadel and Clayton, 1997). In O. tshawytscha the control region is $986 \mathrm{bp}$, similar to the size of $S$. salar (1,006 bp), O. mykiss (1003 bp), S. fontinalis (964 bp), S. alpinus (998 bp) and $C$. lavaretus (1,076 bp).

Adjacent to the tRNA ${ }^{\text {Pro }}$ gene it is possible to find in the D-loop region the putative TAS sequences associated with premature termination of the replication cycle (Taanman, 1999), the polypirimidine track that varies between 24 to $25 \mathrm{~T}$ and $\mathrm{C}$ and that could be a site of interaction with the mitochondrial single-strand-DNAbinding protein (Mignotte et al., 1985), and the imperfect direct repeat found in the right domain close to the $\mathrm{tRNA}^{\mathrm{Phe}}$, region that harbor the transcription promoters in human and mouse (Clayton 1992; Taanman 1999). The CBS motifs CSB-2 and CSB-3 near the origin of replication are highly conserved in the six salmonid species studied as shown in Figure 3. At approximately the position expected for the CSB-1 motive, relative to CSB-2, the sequence 5' ACATA is found in all the fish, 

O. tshawytscha TAAACCCCCCTACCCCCCT
O. tshawytscha
TGTTAAACCCCTAAACCAG
O. mykiss
TAAACCCCCCTACCCCCCT
O. mykiss
TGTTAAACCCCTAAACCAG
S. salar
CAAACCCCCCTACCCCCCT
S. salar
TGTCAAACCCCTAAACCAG
S. alpinus
TAAACCCCCCTACCCCCCT
S. alpinus
TGTTAAACCCCTAAACCAG
S. fontinalis
TAAACCCCCCTACCCCCCT
S. fontinalis
TGTTAAACCCCTAAACCAG
C. lavaretus
TAAACCCCCCTACCCCCCT
C. lavaretus7
TGTCAAACCCCAAAACCAG

\section{Figure 3}

Comparative alignment of CSB motifs identified in the control region of the mtDNA of $O$. $t s$ hawytscha and five other salmonids species.

which is an imperfect motif if compared with the CSB-1 of mouse and human (Walberg and Clayton 1981; Shadel and Clayton 1997) and already discussed by Digby et al., (1992).

It was reported that in the left domain of the control region of $O$. mykiss there is an ORF corresponding to 102 codons (Digby et al., 1992). However, we were unable to find similar coding region in the control region of the other salmonids.

\section{The L-strand replication}

It has been described previously that in the mtDNA of several species there is a putative origin of L-strand replication in a cluster of five tRNAs genes (WANCY region) and between the tRNA ${ }^{\text {Asn }}$ and tRNA ${ }^{\text {Cys. This }}$ sequence has the potential to fold in a stemloop secondary structure with several characteristics. In human mtDNA the 5'GCCGG-3' motif is involved in the transition from RNA to DNA synthesis (Hixson et al., 1986), and the same sequence was found in this region of $O$. tshawytscha as well as in other salmonids species (Fig. 4). The stem sequence is conserved among vertebrates, whereas the loop sequence is more variable (Fig. 4). It is interesting that the loop of $O$. tshawytscha is the shortest one (11 nucleotides) compared with the longest loop of $O$. mykiss of 17 nucleotides. In all the mammalian mtDNA already sequenced the loop is a T-rich sequence that was proposed to be necessary for the initiation of the L-strand replication by a RNA primase (Taanman, 1999). This is in contrast with the loop of $O$. tshawytscha which is C-rich similar to other salmonids (Fig. 4). Therefore, it seems that the initiation of L-strand replication is not restricted to a stretch of $\mathrm{T}$ as previously suggested (Taanman, 1999) but rather to a stretch of polypirimidine.

The sequence in the control region close to the gene of tRNA ${ }^{\text {Pro }}$ gene, shows great variation among these important species for the salmon industry, characteristic that offers an important mtDNA markers to be use to study the $O$. tshawytscha population and for the certification of eggs and smolts.

\section{ACKNOWLEDGEMENTS}

We are grateful to Dr. Mario Rosemblatt and Arturo Yudelevich for helpful discussion during the course of this research and critical reading of this manuscript. 

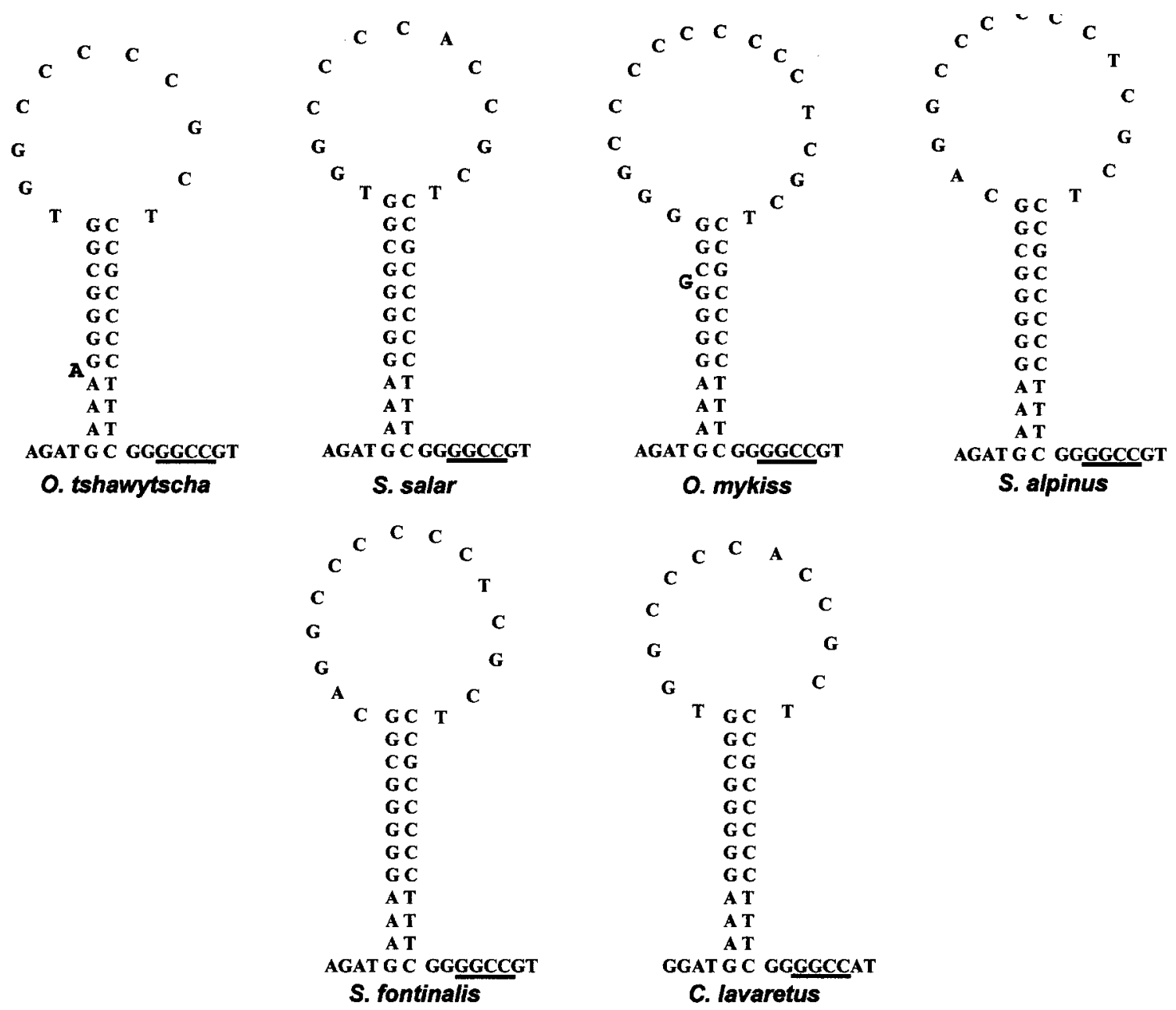

\section{Figure 4}

Theorethical secondary structure for the replication origin of the L-strand of $O$. tshawytscha. The structure is compared with that of S. salar, O. mykiss, S. alpinus, S. fontinalis and C. lavaretus. The nucleotide sequences of the $\mathrm{H}$-strand template are shown. The sequence associated with the transition between RNA synthesis and DNA synthesis is underlined.

\section{REFERENCES}

AGUAYO J, MIQUEL A, ARANKI N, JAMETT A, VALENZUELA PDT, BURZIO LO (2002) Detection of Piscirickettsia salmonis in fish tissues by an enzyme-linked immunosorbent assay using specific monoclonal antibodies. Dis Aquat Org 49: 33-38

ALTSCHUL SF, MADDEN TL, SCHAFFER AA, ZHANG J, ZHANG Z, MILLER W, LIPMAN DJ (1997) Gapped BLAST and PSI-BLAST: a new generation of protein database search programs. Nucleic Acids Res 25: 3389-3402

ANDERSON S, BANKIER AT, BARRELL BG, DE BRUIJN MH, COULSON AR, DROUIN J, EPERON IC, NIERLICH DP, ROE BA, SANGER F, SCHREIER PH, SMITH AJ, STADEN R, YOUNG IG (1981) Sequence and organization of the human mitochondrial genome. Nature 290: 457-465
CLAYTON DA (1992) Transcription and replication of animal mitochondrial DNAs. Int. Rev. Cytol. 141: 217-232

DIGBY TJ, GRAY MW, LAZIER CB (1992) Rainbow trout mitochondrial DNA: sequence and structural characteristics of the non-coding control region and flanking tRNA genes. Gene 118, 197-204

DOIRON S, BLIER PU, BERNATCHEZ L (1999) NCBI Access $\mathrm{N}^{\circ} \mathrm{AF} 154851$

DOIRON S, BLIER PU, BERNATCHEZ L (2002) NCBI Access N ${ }^{\circ}$ NC_000860

FRYER JL, MAUELL MJ (1997) The Rickettsia: an emerging group of pathogens in fish. Emerg. Infect. Dis. 3: $137-144$

HIXSON JE, WONG TW, CLAYTON DA (1986) Both the conserved stem-loop and divergent 5'-flanking sequences are required for initiation at the human mitochondrial origin of light-strand DNA replication. J Biol Chem 261: 2384-2390 
HURST CD, BARTLETT SE, DAVIDSON WS, BRUCE IJ, (1999) The complete nucleotide sequence of the mitochondrial DNA of the Atlantic salmon, Salmo salar. Gene 239: 237-242

JAMETT A, AGUAYO J, MIQUEL A, MULLER I, ARRIAGADA R, BECKER MI, VALENZUELA PDT, BURZIO LO (2001) Characterization of monoclonal antibodies against Piscirickettsia salmonis. J Fish Dis 24: $205-215$

KOBAYASHI S, AMIKURA R, MUKAI M (1998) Localization of mitochondrial large ribosomal RNA in germ plasm of Xenopus embryos. Current Biol 8: $1117-1120$

LANNAN CN, WINTON JR, FRYER JL (1984) Fish cell lines: establishment and characterization of nine cell lines from salmonids. In Vitro 20:671-676

MIGNOTTE B, BARAT M, MOUNOLOU JC (1985) Characterization of a mitochondrial protein binding to single-stranded DNA. Nucleic Acids Res 13: 1703-1716

MIYA M, NISHIDA M (2000) Use of Mitogenomic Information in Teleostean Molecular Phylogenetics: A Tree-Based Exploration under the MaximumParsimony Optimality Criterion. Mol Phylogenet Evol 17: 437-455

NIIKURA T, HASHIMOTO Y, TAJIMA H, NISHIMOTO I. (2002) Death and survival of neuronal cells exposed to Alzheimer's insults. J Neurosci Res 70: 380-391

OJALA D, MONTOYA J, ATTARDI G (1981) tRNA punctuation model of RNA processing in human mitochondria. Nature 290: 470-474

PHILLIPS RB, OAKLEY TH (1997) Phylogenetic relationships among the Salmonidae based on nuclear DNA and mitochondrial DNA sequences. In: KOCHER T, STEPIEN C (eds) Molecular Systematics of Fishes. San Diego: Academic Press. pp:145-162

ROE BA, MA DP, WILSON RK, WONG JF (1985) The complete nucleotide sequence of the Xenopus laevis mitochondrial genome. J Biol Chem 260: 9759-9774

SAMBROOK J, FRITSCH E, MANIATIS T (1989) Molecular Cloning, A Laboratory Manual. $2^{\text {nd }}$ ed, New York: Cold Spring Harbor Laboratory Press

SHADEL GS, CLAYTON DA (1997) Mitochondrial DNA maintenance in vertebrates. Ann Rev Biochem 66: 409-435
STOVER CK, PHAM XQ, ERWIN AL, MIZOGUCHI SD, WARRENER P, HICKEY MJ, BRINKMAN FS, HUFNAGLE WO, KOWALIK DJ, LAGROU M, GARBER RL, GOLTRY L, TOLENTINO E, WESTBROCK-WADMAN S, YUAN Y, BRODY LL, COULTER SN, FOLGER KR, KAS A, LARBIG K, LIM R, SMITH K, SPENCER D, WONG GK, WU Z, PAULSEN IT, REIZER J, SAIER MH, HANCOCK RE, LORY S, OLSON MV (2000) Complete genome sequence of Pseudomonas aeruginosa PA01, an opportunistic pathogen. Nature 406: 959-964

SULIJOADIKUSUMO I, HORIKOSHI N, USHEVA A (2001) Another function for the mitochondrial ribosomal RNA: protein folding. Biochem 40: 1155911564

TAANMAN JW (1999) The mitochondrial genome: structure, transcription, translation and replication. Biochim Biophys Acta 1410: 103-123

VALENZUELA PDT, BURZIO LO, ROSEMBLATT M, YUDELEVICH A, BERNALES, S, ENGEL E, ERAZO E, HERNÁNDEZ C, HUARACAN B, ARAYA P, MARTÍNEZ R, MIQUEL A, MORALES C, SOZA C, VILLEGAS J, WILHELM V (2001) Sequence and applications of the Piscirickettsia salmonis genome. Biol Res 34: R17

VILLEGAS J, ZARRAGA AM, MULLER I, MONTECINOS L, WERNER E, BRITO M, MENESES AM, BURZIO LO (2000)A novel chimeric mitochondrial RNA localized in the nucleus of mouse sperm. DNA Cell Biol 19: 579-588

VILLEGAS J, ARAYA P, BUSTOS-OBREGON E, BURZIO LO (2002) Localization of the $16 \mathrm{~S}$ mitochondrial rRNA in the nucleus of mammalian spermatogenic cells. Mol Hum Reprod 8: 977-983

WALBERG MW, CLAYTON DA (1981) Sequence and properties of the human KB cell and mouse L cell Dloop regions of mitochondrial DNA. Nucleic Acids Res 9: 5411-5421

WOLSTENHOLME DR (1992) Animal mitochondrial DNA: structure and evolution. Int Rev Cytol 141:173-216

ZARDOYA R, GARRIDO-PERTIERRA A, BAUTISTA JM (1995) The complete nucleotide sequence of the mitochondrial DNA genome of the rainbow trout, Oncorhynchus mykiss. J Mol Evol 41: 942-951 